\title{
Dynamics of Two Anadromous Species in a Dam Intersected River: Analysis of Two 100-Year Datasets
}

\author{
Ulisses M. Azeiteiro ${ }^{1, *}$, Mário J. Pereira ${ }^{1}$, Amadeu M. V. M. Soares ${ }^{1}{ }^{\circledR}$, Heitor O. Braga ${ }^{1}{ }^{\circledR}$, Fernando Morgado ${ }^{1}$,

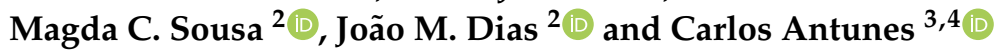 \\ 1 CESAM - Centre for Environmental and Marine Studies \& Department of Biology, University of Aveiro, \\ 3810-193 Aveiro, Portugal; mverde@ua.pt (M.J.P.); asoares@ua.pt (A.M.V.M.S.); heitorob@ua.pt (H.O.B.); \\ fmorgado@ua.pt (F.M.) \\ 2 Department of Physics \& CESAM-Centre for Environmental and Marine Studies, University of Aveiro, \\ 3810-193 Aveiro, Portugal; mcsousa@ua.pt (M.C.S.); joao.dias@ua.pt (J.M.D.) \\ 3 Interdisciplinary Centre of Marine and Environmental Research (CIIMAR), University of Porto, Terminal de \\ Cruzeiros de Leixões, Av. General Norton de Matos s/n, 4450-208 Matosinhos, Portugal; \\ cantunes@ciimar.up.pt \\ 4 Aquamuseu do Rio Minho, Parque do Castelinho, 4920-290 Vila Nova de Cerveira, Portugal \\ * Correspondence: ulisses@ua.pt
}

check for

updates

Citation: Azeiteiro, U.M.; Pereira, M.J.; Soares, A.M.V.M.; Braga, H.O.; Morgado, F.; Sousa, M.C.; Dias, J.M.; Antunes, C. Dynamics of Two Anadromous Species in a Dam Intersected River: Analysis of Two 100-Year Datasets. Fishes 2021, 6, 21. https://doi.org/10.3390/ fishes6020021

Academic Editors: Maria Angeles Esteban and J. Todd Petty

Received: 21 April 2021

Accepted: 26 May 2021

Published: 5 June 2021

Publisher's Note: MDPI stays neutral with regard to jurisdictional claims in published maps and institutional affiliations.

Copyright: (c) 2021 by the authors. Licensee MDPI, Basel, Switzerland. This article is an open access article distributed under the terms and conditions of the Creative Commons Attribution (CC BY) license (https:// creativecommons.org/licenses/by/ $4.0 /)$.

\begin{abstract}
Long-term time-series datasets are key for assessing the population dynamics of fish species with economic interest. This study examines two 100-year datasets for sea lamprey Petromyzon marinus and allis shad Alosa alosa from the Minho River. This basin on the Iberian Peninsula is home to one of the largest populations at the southern distribution limit of these critically endangered anadromous fish species. Besides assessing the importance of the environmental drivers of fish capture data (temperature, salinity, upwelling, precipitation, and climatic oscillation), this study also assesses how dam construction affected these populations using intervention analysis-A statistical tool to detect significant breakpoints in time series data. Results showed contrasting trends between sea lamprey and allis shad, with the number of captured fish from the first progressively improving from 1914 to 2017, and the latter recording a significant decline over time. Although no significant correlations were detected between fishing data and environmental variables, some of the identified breakpoints in the time series data matched the dates when the major dams in Minho River were built. Other historical activities associated with mining might explain the notable changes detected in the trends, while issues associated with illegal, unreported, and unregulated capture data are also discussed.
\end{abstract}

Keywords: Alosa alosa; Petromyzon marinus; dam construction; habitat fragmentation; Minho River

\section{Introduction}

Anadromous fish migrate from marine to freshwater habitats to spawn and complete their life cycle. These migratory fish represent an important share of coastal and marine fisheries [1], yet most species are of conservation concern. This is due to their small and river-specific populations [2], complex life cycles with multiple life stages, and spawning migration paths that cross multiple habitats [3]. These traits expose anadromous fish populations to a greater number of stressors than exclusively marine or freshwater species. Significant population declines have thus been observed during the last decades, particularly in human-impacted ecosystems [3,4].

Dams are a major threat to the preservation of anadromous species, as they pose significant obstacles to migration, affect connectivity, and decrease habitat quality by altering normal seasonal variations in riverine systems [5-8]. Climate change also poses a significant threat to these fish species [9]. Both sea surface temperature and riverine water flow affect riverine environmental conditions as a function of regional and local climate $[4,9,10]$. In addition, the irregular environmental patterns in river flow and water 
temperature, driven by the occurrence of more frequent and extreme weather events associated with climate change, are known to impact anadromous species [11]. Dams and climate change synergistic interactions thus lead to habitat modifications that pose significant challenges to the resilience of anadromous fish populations [12].

To ensure the conservation of anadromous fish species and the sustainable management of fishing pressure, it is important to pinpoint and understand the threats imposed by anthropogenic stressors [2]. Reliable, long-term datasets are key to assessing and a better understanding of variations in life history, population parameters, population dynamics, and the relationship between stock and recruitment [13]. However, for decades, scientists have been using relatively short-term datasets with geographic or temporal gaps [14]. This situation has been addressed by the recently established ICES Working Group on Datalimited diadromous species (WGDAM), part of the larger ICES Working Group on Science to Support Conservation, Restoration, and Management of Diadromous Species [15]. Nineteen anadromous fish species were identified as data-limited for which additional efforts are needed to gather data. This list includes sea lamprey, Petromyzon marinus Linnaeus, 1758, and allis shad Alosa alosa Linnaeus, 1758, both evidencing declining populations and facing extinction caused by over-harvesting and habitat loss due to the effects of dams. The life cycle of sea lamprey includes a freshwater larval phase and a post-metamorphic marine phase that in total comprises 5-9 years [16]. Lampreys nest in the main river and tributaries using large stones [17]. The larval phase starts immediately after fecundation, with the embryonic and proammocoete stages [18]. After the absorption of the yolk, the young ammocoetes, approximately $7 \mathrm{~mm}$ in length, emerge from the sand of the nests 3 weeks after the completion of spawning and are carried downstream to be deposited by the slackening current in areas of fine substrate and feed by filtration $[18,19]$.

After metamorphosis, the juveniles migrate to the sea and evidence is growing that within the rivers of their natural range hematophagic feeding may begin in freshwater [16]. After 1-2 years the sea lamprey adults return to fresh water and complete their life cycle after 5-9 years by migrating upstream to spawn and die. Allis shad also enter rivers and swim hundreds of kilometers upstream into their natal river seeking shallow waters with gravel substrates to spawn. In the Minho River, the spawning grounds are in the main course, not entering into tributaries, near the Frieira dam [20]. Spawning occurs during spring and summer, in shallow waters, and over gravel substrate [21,22]. The adults usually die after spawning. Allis shad larvae hatch within 4-5 days, spend summer in freshwater, and migrate to estuaries during autumn. Early life stages of $A$. alosa then return to the ocean before they complete their first year of life [23,24].

Portugal is home to the largest populations of A. alosa and P. marinus at their southern limit of distribution [15], where both fish species are socio-economically important [25-28]. Particularly in the Minho River basin in northern Portugal, both species have been commercially targeted for several centuries by riverside communities [22,27-29]. Landings, possibly underestimated, are the only source of information on the mortality of both species. The Minho River flows along $300 \mathrm{~km}$ in the north-western Iberian Peninsula, draining a basin area of 17,080 $\mathrm{km}^{2}$ [30,31]. In terms of biodiversity, the international Minho River is a Natura 2000 EU site and the estuary is classified as a Special Protection Area under the EU Birds Directive (Directive 2009/147/EC), The Minho estuary has been considered to be at a low chemical contamination level, not raising serious concern [32]. This river is dammed at several locations along its course, being the production of electricity one of the main economic activities in its basin [33]. Five major dams were constructed along the Minho River within a 15-year period: 1955 (Os Peares), 1963 (Belesar), 1966 (Velle), 1969 (Castrello de Miño), and 1970 (Frieira) (Figure 1). In the Spanish Minho basin, above the Frieira dam, there are more than 60 dams distributed over the tributaries and built mainly in the 1950s and 1960s. Despite the economic benefits and benefits of flood prevention, dams have a negative effect on biodiversity and aquatic biochemistry [34]. 


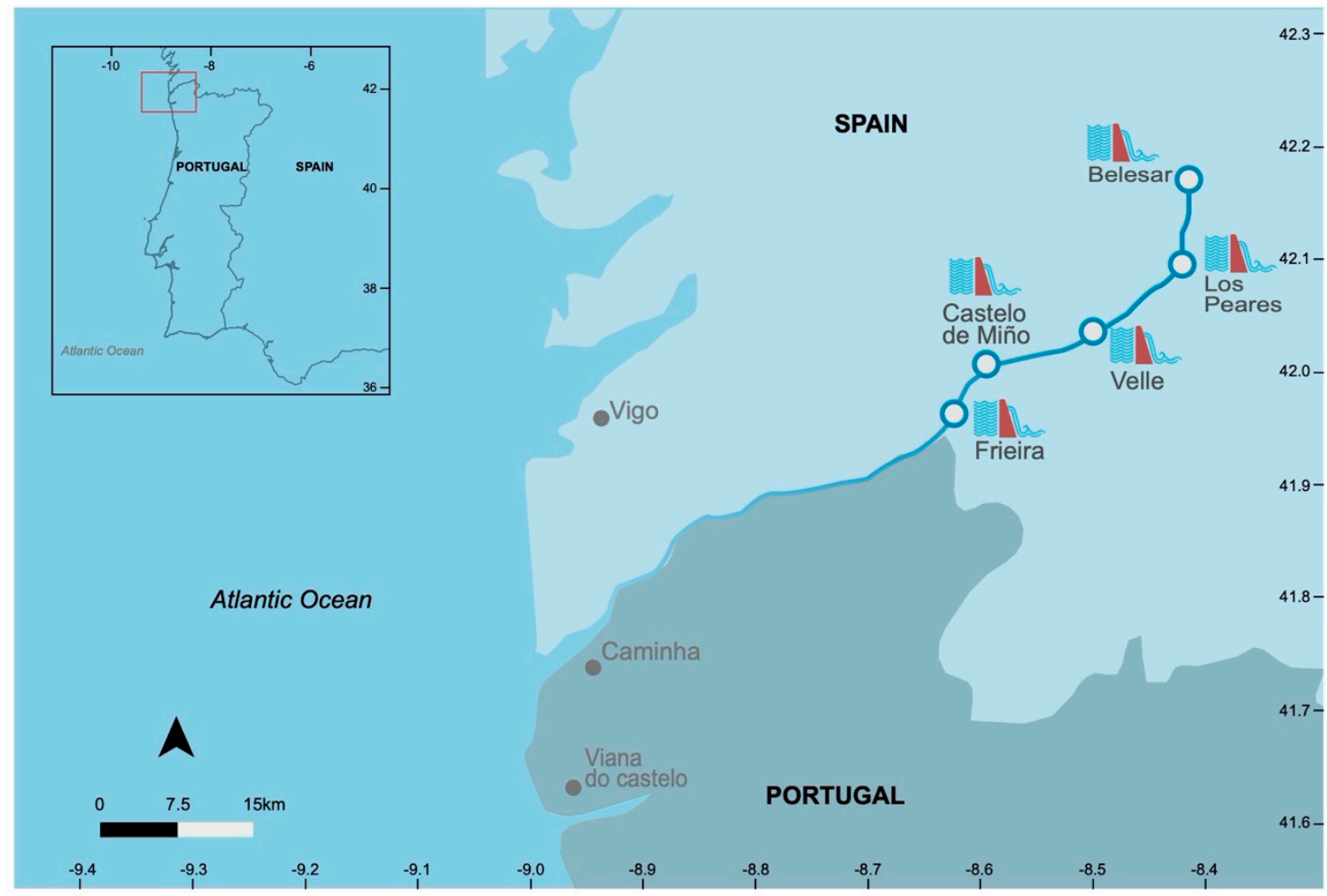

Figure 1. Map of the Minho River international section and the location of major dams constructed in the past 100 years.

An important feature of the Minho River is its lower $77 \mathrm{~km}$ stretch that forms an international boundary between northern Portugal and the Spanish Autonomous Region of Galicia, which poses challenges to the management of aquatic resources with an economic interest, such as sea lamprey and allis shad. Licensing, surveillance, and monitoring of Portuguese and Spanish fishers is controlled by an international river committee that annually stipulates exploitation rules [29]. In addition, Portuguese authorities highly regulate and monitor fish captures in the Minho River since 2003, when these two fish species were listed under the Protected Fauna Species of the Bern Convention Annex III (Convention on the Conservation of European Wildlife and Natural Habitats).

The present study utilizes the extensive and unparalleled capture datasets for sea lamprey and allis shad in the Minho River, building upon the preliminary study by [26]. The time series extends from 1914 to 2017 and provides a unique opportunity as case studies to investigate the long-term dynamics of these two anadromous fish populations before and after the construction of dams, and the possible interactive disruptions induced by long-term environmental changes. We hypothesize that the effect of dams on these two fish species might differ because: (1) allis shad is more affected than sea lamprey by habitat fragmentation and loss [29,35]; and (2) changes in flow regimes can show speciesspecific constraints or stimulus to anadromous fish migration [36]. Due to the international location of the Minho River, this study also aims to highlight the potential impact of unilateral decisions associated with damming in a particular territory and its consequences for fisheries management of species whose distribution knows no political borders.

\section{Materials and Methods}

\subsection{Data}

The data supplied by the Port Authority of Caminha (Minho, Portugal) reported the total annual landings of sea lamprey and allis shad (number of fish) from the fishing activity in Minho River estuary (40 km) for 1914-2017 from the Portuguese fishers. Although captures data without information on fishing effort is not a measure of abundance, it is assumed that landings reflect the trend in the abundance since we are looking at major 
changes in catch over a very long period of time ( 100 years). Unfortunately, no dedicated fishing effort data are available to construct typical fisheries data abundance indices, such as catch per unit effort for either time series. Although the number of boats has been recorded and an increase starting in the early 1980s (maximum in 1985 with 735 boats) was detected, followed by a decrease to approximately 300 boats and 400 Portuguese fishermen currently registered, these numbers do not reflect the fishing efforts on sea lamprey and allis shad specifically. In addition to the effect of fishing effort in the capture data analyzed here, captures might also be associated with the historical shift in the type of (and regulated) fishing methods targeting migratory fish. The first directive approving the rules for fishing in the International Stretch of the Minho River was published in 1897 and since then several other regulations and updates have followed, the last in 2008. These documents establish the legal framework that regulates the fishing activities in Minho River and regularly revise the list of the approved fishing techniques for these species.

Available environmental datasets relevant for the study area and time frame were assembled. These included monthly data for mean sea surface temperature, air temperature, precipitation at the mouth of Minho River from 1914 to 2017, upwelling index for the Rias Baixas region in Spain (1967-2017), and North Atlantic Oscillation index, as a proxy for climatic stability (1914 to 2017) (Table 1). Because capture data was reported by the Caminha Port Authority on a yearly basis, the yearly median of all environmental variables was used. The environmental variables were selected based on their potential to directly affect aquatic habitats and both species' life cycles. Precipitation and temperature might be key for understanding populations' dynamics as the species' ideal reproductive conditions may not be fulfilled due to altered freshwater conditions as a consequence of climate change [37]. Rain also affects river flow, which is an important aspect of the life cycle of migratory fishes during both downriver and upriver migrations [38]. The upwelling index was chosen based on the importance it may have on shaping the physical estuarine environment and establishing a causative link between biological processes and large climatic processes [39]. The western Mediterranean precipitation regime is also strongly influenced by the North Atlantic Oscillation and it is responsible for approximately $40 \%$ of winter precipitation [40].

Table 1. Time coverage and source of all collected datasets.

\begin{tabular}{|c|c|c|}
\hline Variable & Time Coverage & Source \\
\hline $\begin{array}{c}\text { Alosa alosa Annual Landings (number of } \\
\text { fish) }\end{array}$ & 1914-2017 & Port Authority of Caminha \\
\hline $\begin{array}{c}\text { Petromyzon marinus Annual Captures } \\
\text { (number of fish) }\end{array}$ & 1914-2017 & Port Authority of Caminha \\
\hline Median sea surface temperature & 1914-2017 & $\begin{array}{c}\text { COBE SST (https: } \\
\text { / / www.esrl.noaa.gov / psd/data/gridded/data.cobe.html); } \\
\text { (accessed date 1 October 2019) Minho River mouth }\end{array}$ \\
\hline Median air temperature & 1914-2017 & $\begin{array}{c}\text { Global Historical Climatology Network } \\
\text { (https://www.esrl.noaa.gov/psd/data/gridded/data.UDel_ } \\
\text { AirT_Precip.html\#detail) for the Minho River mouth (accessed } \\
\text { date } 1 \text { October 2019) }\end{array}$ \\
\hline Median Upwelling index & $1967-2017$ & $\begin{array}{l}1967 \text { to 2017: Instituto Español de Oceanografia } \\
\text { (http: / / www.indicedeafloramiento.ieo.es/index_UI_en.html) } \\
\text { (accessed date } 1 \text { October 2019); for the Rias Baixas region } \\
\text { (Spain) }\end{array}$ \\
\hline Total yearly precipitation & $1914-2017$ & $\begin{array}{c}1914 \text { to 2013: Global Precipitation Climatology Centre } \\
\text { (https: / / www.esrl.noaa.gov / psd/data/) (accessed date } 1 \text { July } \\
\text { 2019); Minho River mouth.2013 to 2017: Era-Interim } \\
\text { (https: / / www.ecmwf.int/en/forecasts / datasets / archive- } \\
\text { datasets / reanalysis-datasets / era-interim) (accessed date 1 July } \\
\text { 2019); Minho River mouth }\end{array}$ \\
\hline North Atlantic Oscillation index & $1914-2017$ & $\begin{array}{l}\text { NOAA's National Centers for Environmental Information } \\
\text { (https: } \\
\text { / / www.esrl.noaa.gov/psd/gcos_wgsp/Timeseries/NAO) } \\
\text { (accessed date 1 October 2019) }\end{array}$ \\
\hline
\end{tabular}


The main threats concern the introduction of exotic species, in particular since the 1990s, climate change while deterioration of water quality has never reached the dramatic situation described for other estuarine areas [32].

\subsection{Analysis of Time Series}

The exploratory analysis assessed Pearson's correlations among environmental variables to examine linearity and determine which variables could be used in the subsequent analysis of fish capture data. The patterns of fish capture data as time series were assessed using Differencing Methods. As no mean cyclical effects were identified, the non-explained variability by the Differencing Methods was considered an error. The correlation structure of the original data was then computed to identify possible forms of (non)stationary model(s) for the stochastic process. This was done by Autocorrelation Functions (ACF) and Partial Autocorrelation Functions (PACF). Stationarity was graphically evaluated before and after Differencing and tested using Unit Root Tests.

For assessing the effect of environmental variables on the observed fish captures, linear and Multiple Regression Analysis of the time series were performed. A forecast of the time series of interest (fish captures) was made assuming a linear relationship with the other time series (environmental variables). Non-linear regressions and autocorrelation in environmental variables were also tested when appropriate. As the upwelling index dataset was incomplete, two linear analyses were conducted for each species: (i) considering all environmental variables but only the years for which all variables had information-intersect data; (ii) considering only the environmental variables with complete data for all years (1914 to 2017).

To explore a causative link between dam construction and fish capture data, an Intervention Analysis approach was used. This approach explicitly and independently incorporated the effect of dam construction over fish captures of the two species of interest. A time series model was built based on each species capture data until 1954 (the last year without dams in Minho River). Both ACF and PACF were considered to estimate the correct model and an Autoregressive Integrated Moving Average (ARIMA) model was identified and estimated for the pre-intervention (pre-dam construction) period. The selected model showed the smallest Akaike Information Criterion (AIC). Once the ARIMA model was estimated, a forecast for the pre-intervention period was made based on this model. Because this forecast was based on the pre-intervention period model, it does not reflect the effect of the intervention. Lastly, this approach allowed assessing the periods where a statistically significant change was recorded in the time series, either positive or negative. All data analyses were conducted in R v3.6.1 in RStudio v1.1.383 (https: / / www.r-project.org) (accessed date 1 October 2019).

\section{Results}

\subsection{Time Series Analysis of Fish Capture and Environmental Data}

Captures of $A$. alosa showed an irregular pattern with a relatively high number of captured individuals between the 1910s and 1940s, marked increases and decreases until 1960, and a constant decrease in capture trends thereafter (Figure 2A). In opposite, landings of sea lamprey were relatively low in the first half of the time series up to the 1950s, followed by an irregular but steadily increasing pattern thereafter (Figure 2B) with the greatest landings occurring in 2009. 

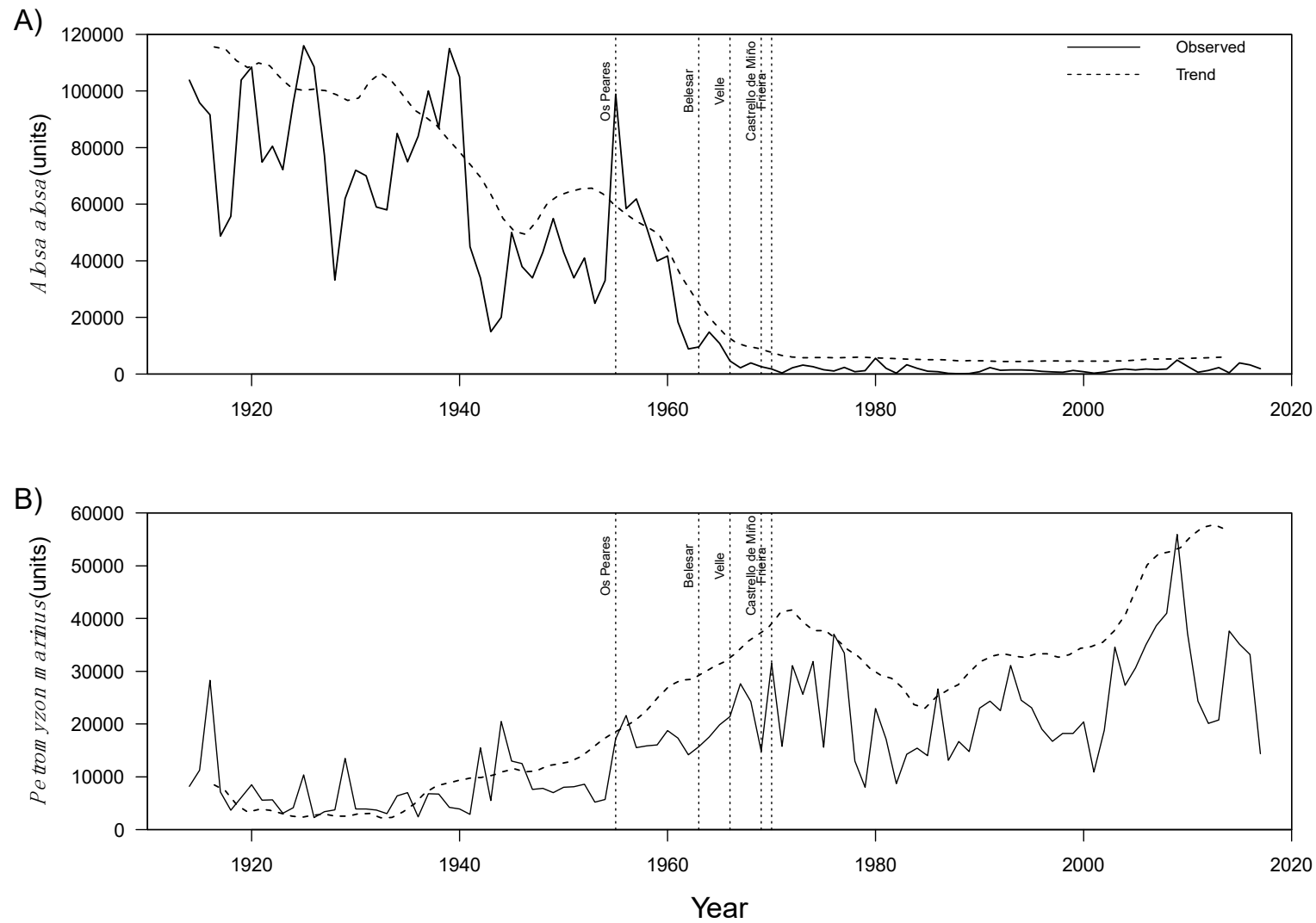

Figure 2. Capture data of Alosa alosa (A) and Petromyzon marinus (B). The observed trends decomposed with time series Differencing Methods are also shown, as well as the dates when the main dams were constructed.

As suggested by the very low $\mathrm{R}^{2}$ values (A. alosa $\mathrm{R}^{2} 0.10$, P. marinus $\mathrm{R}^{2} 0.20$ ), the linear models fitted for the captures of each species using intersect environmental data did not yield a good representation, even though residual analysis showed that the model was well adjusted to the data (random residuals not associated with any of the explanatory variables). Nevertheless, none of the regressors showed a significant effect on fish captures, suggesting that the selected environmental variables were not the main drivers of the observed trends in A. alosa and P. marinus captures (Supplementary Materials). Similar results were recorded for linear models using only the environmental variables with complete data for all years, with a low $R^{2}$ (A. alosa $R^{2} 0.02$, P. marinus $R^{2} 0.01$ ) and no significant effects of the environmental regressors (Supplementary Materials). This motivated the subsequent analysis based on specific events (Intervention Analysis), as a more suited approach to identify statistically significant changes in fish capture data.

\subsection{Intervention Analysis}

To identify the best ARIMA model, data were transformed and analyzed for stationarity. Log transformation was first performed to reduce data fluctuation and stationise the data without removing its characteristics and trends. Preliminary ARIMA models were fitted with the data transformations that presented the best results for each species dataset. Although the previous analyses indicated that models with $\log$ and $\Delta \log$ transformation would perform better (Supplementary Materials), ARIMA models were fitted with all data transformations, and the best model selected based on AIC (Supplementary Materials). A forecast was subsequently produced considering the absence of intervention, i.e., dam construction. Results show that if the pre- 1955 conditions remained similar, the expected trends in the capture data would be different. For A. alosa, the predicted captures showed a different pattern from that observed, with regular fish captures and no notable breaks 
(Figure 3). However, for P. marinus the forecast data were somehow similar to capture data, but without the notable increase recorded in the 1960s (Figure 4).
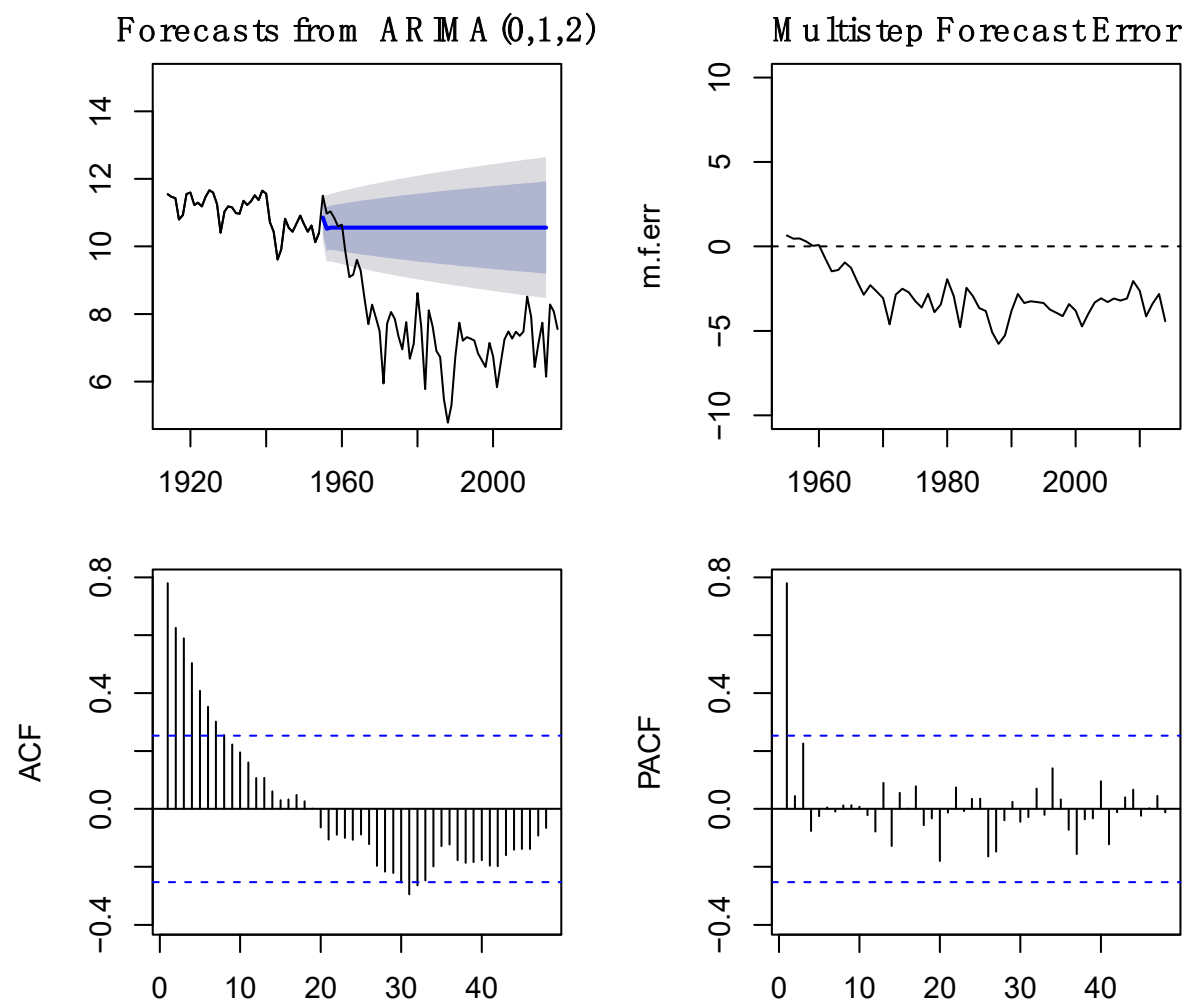

Figure 3. Forecast of captures without dam construction using the ARIMA models based on pre-intervention capture data for Alosa alosa. Model accuracy was evaluated through its multistep error, ACF, and PACF. Forecasts are shown by the blue line and shaded grey areas.
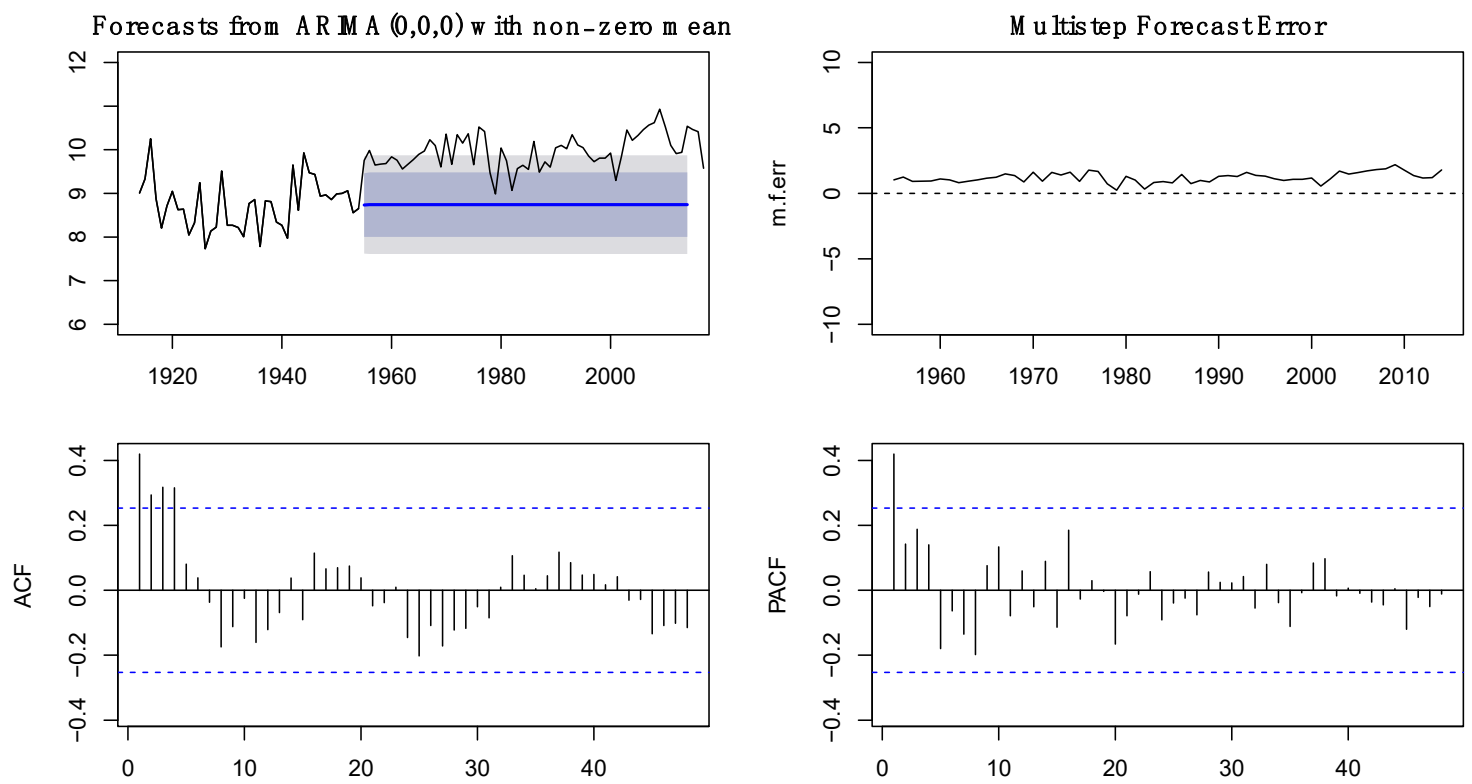

Figure 4. Forecast of captures without dam construction using the ARIMA models based on pre-intervention capture data for Petromyzon marinus. Model accuracy was evaluated through its multistep error, ACF, and PACF. Forecasts are shown by the blue line and shaded grey areas. 
Structural breaks were also investigated for each time series to indicate the dates where a specific and abrupt variation in the data was observed. The statistical significance of the breakpoints was calculated together with their confidence intervals (Supplementary Materials). Structural breaks in A. alosa capture data were identified for two periods: 19381944 and 1959-1963 (Figure 5A). Concerning P. marinus, calculated breakpoints were also identified for two periods: 1954-1956 and 1994-2005 (Figure 5B).
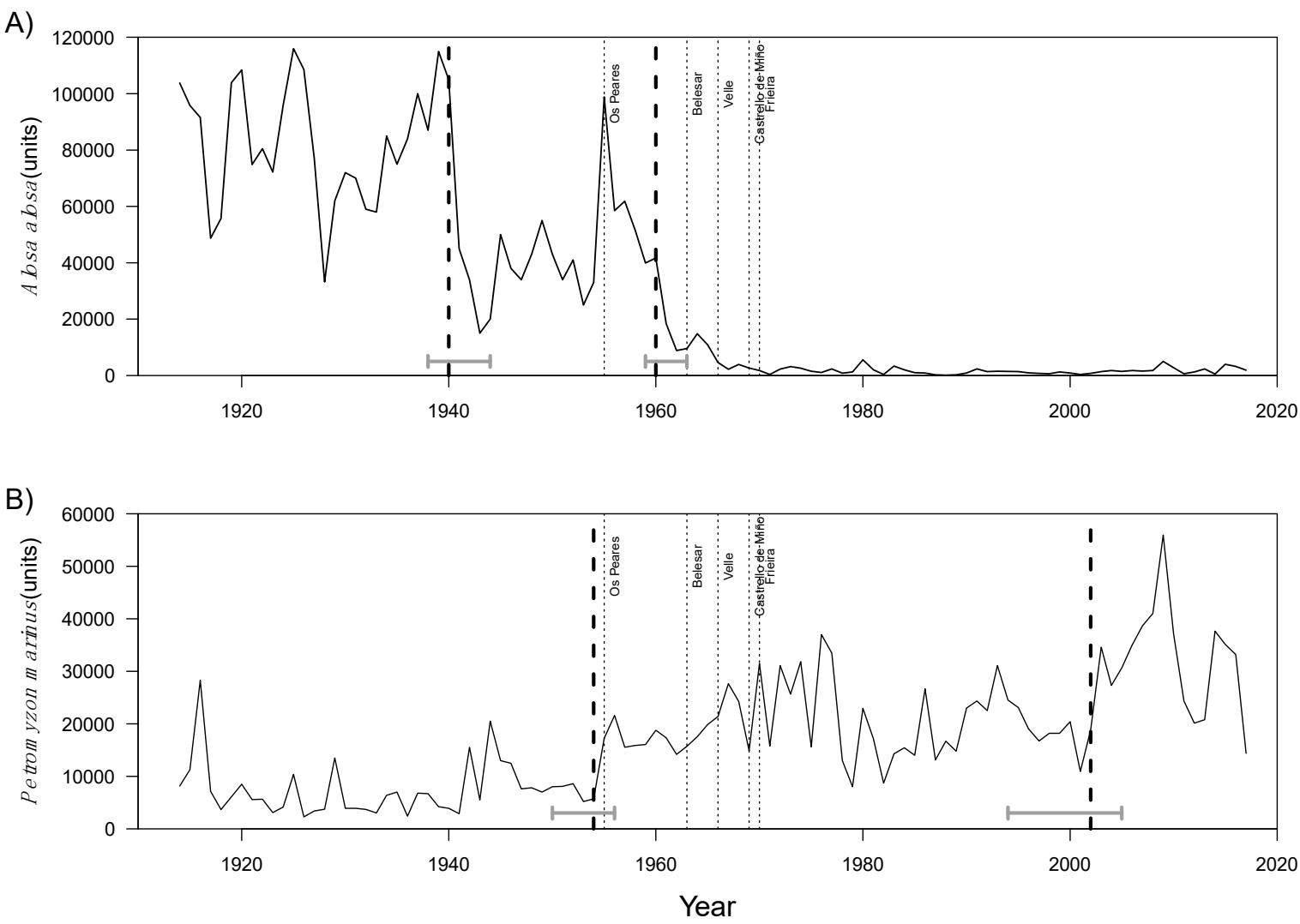

Figure 5. Capture data of Alosa alosa (A) and Petromyzon marinus (B) with the respective breakpoints and confidence intervals $(2.5 \%$ and $97.5 \%)$ resulting from the Intervention Analysis. The dates when the main dams were constructed are also shown.

\section{Discussion}

Understanding the natural and anthropogenic drivers affecting the long-term population dynamics of sea lamprey and allis shad in the Minho River can provide valuable information for future conservation and fisheries management actions of anadromous species. Indeed, the Minho River basin has been the target of many conservation case studies of biodiversity loss likely associated with the interactive effects of anthropogenic pressures, such as dam construction, climate change, and biological invasions (e.g., [30,32,41]). Accordingly, the present study used two long-term datasets to assess how different environmental variables and anthropogenic drivers are affecting allis shad and sea lamprey populations. Contrasting trends were recorded, with allis shad being affected by dam construction, whereas sea lamprey showed increasing capture numbers with no evident link to damming.

Despite the theorized expectations that selected environmental variables would explain the significant variation in allis shad and sea lamprey landings, our analyses detected no significant relationships (Supplementary Materials). It is possible that the use of such long-term datasets with yearly data does not capture seasonal harvest variation and seasonal heterogeneity of the environmental drivers that are known to affect the life cycle of these two fish species [26,32]. Local and regional environmental processes have been spatially correlated in the Minho River basin in the north-western Iberian coast, particularly 
river discharge, upwelling, and climatic oscillation [42-45]. However, likely driven by the interactive effects of climate change and dams, an artificial separation has been imposed and correlations started to be lagged.

In addition to environmental drivers, human-introduced structures, such as dams, are known to directly disrupt fish migrations and reduce available spawning habitats [12]. This was validated by the Intervention Analysis based on the landings recorded before major dams were constructed in the Minho River, i.e., up to 1955 . For each species, the forecast based on pre-dam data differed from the observed landings following dam construction; the number of captured sea lamprey increased over time, whereas that of allis shad notably decreased. These opposite trends are probably due to an increase in catchability resulting from the prevalence of drifting trammel nets for both species to detriment of the algerife that was earlier used for allis shad and harpoons traditionally used for sea lamprey [29]. The detected breakpoints (years at which an abrupt variation in data occurred) and their corresponding confidence intervals partially matched the years in which dams were constructed along the Spanish section of Minho River (i.e., 1955 to 1969). In particular, the first breakpoint for sea lamprey (1954-1956) matched the construction date of the Os Peares dam in 1955, whereas the second breakpoint for allis shad (1959-1963) was recorded immediately before the construction date of the Belesar dam in 1963.

The decline in shad populations of Minho River was previously reported [26,32], and likely associated with the loss in the potentially available habitat in this river. This decrease was largely motivated by constraints in the 1960's [46], the decade during which three of the Minho River dams were built with negative consequences for the spawning areas of this species [47]. Previous findings and hypotheses on the causes of allis shad massive population decrease in the 1960s were confirmed in the present study using a statistical tool that identifies significant breakpoints in time series data. This is also supported by a large decrease in river discharge caused by dam construction in the 1960s [48]. However, the results of the Intervention Analysis suggest a first breakpoint in the 1940s, which is not associated with the five major dams identified for the Minho River. It is known that the Minho River basin has more than 50 dams and other barriers beyond the five major ones considered here, which affect natural river flow, fragment the freshwater habitat and create obstacles to fish migration [32]. Allis shad is particularly susceptible to physical barriers that prevent individuals from reaching natural spawning areas, even if equipped with fishways [49]. In addition, spawning grounds adjacent to dams are affected by the dramatic variability between strong discharges and water retention that affect egg viability and nest exposure, thus reducing reproductive success and recruitment [31]. Besides damming, and although our findings suggest no long-term correlation between precipitation data and fish captures, this first breakpoint in the 1940s may be associated with extreme weather events resulting in a notable decrease in precipitation, as reported by [44] between 1937 and 1945 for the Minho region as it is common to all migratory fish landings data series (including Atlantic salmon, whose data are not presented in this study). Lastly, the allis shad population might have been affected by the environmental impacts driven by intensive mining activities recorded in the Minho River basin during the 1930s and 1950s, coincident with the Second World War and the Korean War [50].

Sea lamprey is not as sensitive as allis shad to habitat loss associated with dam construction [29], as evidenced by the capture data (Figure 5B). Indeed, sea lamprey capture data showed an increasing trend over time and most of the major dams considered here were not associated with statistically significant breaking points. Sea lamprey, unlike allis shad, uses tributaries as reproduction habitats [36,51]. Available habitats and their quality after the construction of dams may have been sufficient to keep recruitment at levels similar to the ones currently known. It is also important to note that isolated extreme precipitation events might positively impact sea lamprey reproductive migration and recruitment [51,52], which would not be captured in the long-term statistical correlation tested in the present study between precipitation and fish capture data. Additionally, lamprey populations are under less pressure than allis shad, because the continental 
geographical area of exploitation is smaller and it is not targeted for sea fishing. The increase in the number of boats in the 1970s and 1980s was due to the increased economic importance of glass eel fishing and comes after the sharp drop in values of the allis shad fishery in the 1960s. Fatela et al. (2014) [44] reported above-average precipitation in the Minho region in the late 1950s and early 1960s, as well as an extreme flood in 2000/2001, which were concomitant with the breakpoints identified in the present study (Figure 5B). Moreover, the increase in sea lamprey captures might be associated with improvements in the sea lamprey catch per unit effort in the late twentieth century, as described for some European rivers [53]. This increase might be due to an increasing fishing effort or catch efficiency [54,55], as well as to changes in illegal, unreported, and unregulated (IUU) fishing [56].

The present study, based on long-term fishing data sets for allis shad and sea lamprey, is, to our knowledge, the first to use Intervention Analysis to statistically support previous hypotheses on dam constructions significantly affecting the population dynamics of these two anadromous fish species [12,26,32]. While negative impacts on both fish populations in the Minho River could have been anticipated, contrasting trends were observed: a marked decrease for allis shad captures and an increasing trend in the captures of sea lamprey. Despite analyzing two unique datasets with over 100 years of landings data, this study encountered a number of challenges in results' interpretation. The lack of detailed environmental and biological data limits the understanding of the population dynamics of anadromous fish species. Additionally, changes in fishing regulations and catch reporting due to IUU fishing are more likely during such long time series, impairing scientists' ability to suggest accurate and efficient management towards sustainable fishing practices, as well as concomitant efforts to conserve marine ecosystems and biodiversity.

Supplementary Materials: The following are available online at https:/ / www.mdpi.com/article/ $10.3390 /$ fishes6020021/s1, Figure S1: Decomposition of the time series data of (A) Alosa alosa and (B) Petromyzon marinus. The top panel shows original captures, the middle panel shows the resulting trend, and the bottom panel shows the random error. Figure S2: Plot of the Bayesian Inference Coefficient (BIC) value against the number of breakpoints for each species: Alosa alosa (A) and Petromyzon marinus (B) capture data., Table S1: Correlation coefficients between the possible pairs of environmental variables. Table S2: Model results of the Linear Regression for Alosa alosa captures with environmental variables as regressors (intersect data). Table S3: Model results of the Linear Regression for Petromyzon marinus captures with environmental variables as regressors (intersect data). Table S4: Model results of the Linear Regression for Alosa alosa captures with environmental variables as regressors. Table S5: Model results of the Linear Regression for Petromyzon marinus captures with environmental variables as regressors. Table S6: Performance measurements of ARIMA models with the original, log, and $\Delta \log$ transformed Alosa alosa capture data. The model with log transformation performed better. Table S7: Performance measurements of ARIMA models with the original, $\log , \Delta \log$, and $\Delta \log 12$ transformed Petromyzon marinus capture data. The model with $\Delta \log$ performed better. Table S8: ARIMA models for pre-intervention (19141954) capture data of Alosa alosa. Two models were tested, with log and $\Delta \log$ transformation, as they had previously shown very small differences. Table S9: ARIMA models for pre-intervention (1914-1954) capture data of Petromyzon marinus. Three models were tested, with $\log , \Delta \log$, and $\Delta \log 12$ transformation, as they had previously shown very small differences.

Author Contributions: U.M.A.: Conceptualization, Writing-Original Draft, Formal analysis, WritingReview \& Editing; M.J.P.: Conceptualization, Writing-Original Draft, Writing-Review \& Editing; A.M.V.M.S.: Writing—Original Draft; H.O.B.: Writing—Original Draft; F.M.: Writing—Original Draft; M.C.S.: Resources, Writing-Original Draft; J.M.D.: Resources, Writing-Original Draft; C.A.: Conceptualization, Writing-Original Draft, Formal analysis, Writing-Review \& Editing. All authors have read and agreed to the published version of the manuscript.

Funding: This research received no external funding.

Data Availability Statement: The sources of all datasets used in this work are reported in the manuscript and available either online or through requests to the Port of Caminha authorities (Portugal). 


\begin{abstract}
Acknowledgments: The authors acknowledge Miguel C. Leal for comments to improve the manuscript. The authors acknowledge Brian Rothschild's comments to improve the manuscript. The publication was carried out in the context of the provision of services called "Valorization of the fishing production of the Minho River-contribution to the management and valorization of fishing products of the Minho River (COOPERMINHO) - Communication and socio-environmental training of the local community for the valorization of the fish resources of the Minho River," financed, via the Municipal Council of Vila Nova de Cerveira, by the program Mar 2020-Programa Operacional Mar 2020 Aviso $\mathrm{n}^{\circ} 5 / 2016$. Thanks are due for the financial support to CESAM, to FCT/MCTES through national funds (UIDB/50017/2020+UIDP/50017/2020), and the co-funding by the FEDER, within the PT2020 Partnership Agreement and Compete 2020. From author HBO thanks are due to CAPES Foundation, Ministry of Education of Brazil (BEX: 8926/13-1), Caixa Postal 250, 70040-020, Brasília-DF, Brazil. From author MCS thanks are due to national funds (OE), through FCT, I.P., in the scope of the framework contract foreseen in the numbers 4, 5, and 6 of the article 23, of the Decree-Law 57/2016, of August 29, changed by Law 57/2017, of July 19. Thanks are due to Instituto Español de Oceanografía for the "Upwelling index data have been obtained from www.indicedeafloramiento.ieo.es, (accessed date 1 October 2019) computed and maintained by Instituto Español de Oceanografía".
\end{abstract}

Conflicts of Interest: The authors declare no conflict of interest.

\title{
References
}

1. FAO. The State of World Fisheries and Aquaculture 2018-Meeting the Sustainable Development Goals; Food and Agriculture Organization of the United Nations: Rome, Italy, 2018.

2. Limburg, K.E.; Waldman, J.R. Dramatic Declines in North Atlantic Diadromous Fishes. BioScience 2009, 59, 955-965. [CrossRef]

3. Waldman, J.; Wilson, K.A.; Mather, M.; Snyder, N. A Resilience Approach Can Improve Anadromous Fish Restoration. Fisheries 2016, 41, 116-126. [CrossRef]

4. Chaparro-Pedraza, P.C.; de Roos, A.M. Environmental change effects on life-history traits and population dynamics of anadromous fishes. J. Anim. Ecol. 2019, 88, 1178-1190. [CrossRef]

5. $\quad$ Dudgeon, D.; Arthington, A.H.; Gessner, M.O.; Kawabata, Z.-I.; Knowler, D.J.; Lévêque, C.; Naiman, R.J.; Prieur-Richard, A.-H.; Soto, D.; Stiassny, M.L.J.; et al. Freshwater Biodiversity: Importance, Threats, Status and Conservation Challenges. Biol. Rev. Camb. Philos. Soc. 2006, 81, 163-182. [CrossRef]

6. Vörösmarty, C.J.; McIntyre, P.B.; Gessner, M.O.; Dudgeon, D.; Prusevich, A.; Green, P.; Glidden, S.; Bunn, S.E.; Sullivan, C.A.; Liermann, C.R.; et al. Global Threats to Human Water Security and River Biodiversity. Nature 2010, 468, 334. [CrossRef]

7. Drouineau, H.; Bau, F.; Alric, A.; Deligne, N.; Gomes, P.; Sagnes, P. Silver eel downstream migration in fragmented rivers: Use of a Bayesian model to track movements triggering and duration. Aquat. Living Resour. 2017, 30, 5. [CrossRef]

8. Schmutz, S.; Moog, O. Dams: Ecological Impacts and Management. In Riverine Ecosystem Management: Science for Governing Towards a Sustainable Future; Schmutz, S., Sendzimir, J., Eds.; Springer International Publishing: Cham, Switzerland, 2018; pp. 111-127.

9. Lassalle, G.; Rochard, E. Impact of twenty-first century climate change on diadromous fish spread over Europe, North Africa and the Middle East. Glob. Chang. Biol. 2009, 15, 1072-1089. [CrossRef]

10. Beamish, R.J. Response of Anadromous Fish to Climate Change in the North Pacific; Taylor \& Francis: Washington, DC, USA, 1995; pp. 123-136.

11. Allen, M.R.; Dube, O.P.; Solecki, W.; Aragón-Durand, F.; Cramer, W.; Humphreys, S.; Kainuma, M.; Kala, J.; Mahowald, N.; Mulugetta, Y.; et al. Global Warming of $1.5^{\circ} \mathrm{C}$. An IPCC Special Report on the Impacts of Global Warming of $1.5^{\circ} \mathrm{C}$ above Pre-Industrial Levels and Related Global Greenhouse Gas Emission Pathways, in the Context of Strengthening the Global Response to the Threat of Climate Change, Sustainable Development, and Efforts to Eradicate Poverty; IPCC: Geneva, Switzerland, 2018.

12. Mattocks, S.; Hall, C.J.; Jordaan, A. Damming, Lost Connectivity, and the Historical Role of Anadromous Fish in Freshwater Ecosystem Dynamics. BioScience 2017, 67, 713-728. [CrossRef]

13. Gordon, T.A.C.; Harding, H.R.; Clever, F.K.; Davidson, I.K.; Davison, W.; Montgomery, D.W.; Weatherhead, R.C.; Windsor, F.M.; Armstrong, J.D.; Bardonnet, A.; et al. Fishes in a changing world: Learning from the past to promote sustainability of fish populations. J. Fish Biol. 2018, 92, 804-827. [CrossRef]

14. Soranno, P.A.; Schimel, D. Macrosystems ecology: Big data, big ecology. Front. Ecol. Environ. 2014, 12, 3. [CrossRef]

15. Wilson, K.; Veneranta, L. Data-limited diadromous species-Review of European status. In ICES Cooperative Research Report No. 348; ICES Working Group: Copenhagen, Denmark, 2019; p. 273.

16. Silva, S.; Servia, M.J.; Vieira-Lanero, R.; Nachón, D.J.; Cobo, F. Haematophagous feeding of newly metamorphosed European sea lampreys Petromyzon marinus on strictly freshwater species. J. Fish Biol. 2013, 82, 1739-1745. [CrossRef] [PubMed]

17. Sousa, R.; Araújo, M.J.; Antunes, C. Habitat modifications by sea lampreys (Petromyzon marinus) during the spawning season: Effects on sediments. J. Appl. Ichthyol. 2012, 28, 766-771. [CrossRef]

18. Potter, I.C. Ecology of larval and metamorphosing lampreys. Can. J. Fish. Aquat. Sci. 1980, 37, 1641-1657. [CrossRef] 
19. Quintella, B.R.; Andrade, N.O.; Almeida, P.R. Distribution, larval stage duration and growth of the sea lamprey ammocoetes, Petromyzon marinus L., in a modified river basin. Ecol. Freshw. Fish 2003, 12, 286-293. [CrossRef]

20. Mota, M.; Antunes, C. A preliminary characterisation of the habitat use and feeding of Allis shad (Alosa alosa) juveniles in the Minho River tidal freshwater wetlands. Limnetica 2012, 31, 165-172.

21. Baglinière, J.L.; Sabatié, R.; Rochard, E.; Alexandrino, P.; Aprahamian, M.W. Theballis shad Alosa alosa: Biology, ecology, range, and status of populations. Am. Fish. Soc. 2003, 35, 85-102.

22. Mota, M.; Antunes, C. First report on the status of Allis shad (Alosa alosa) in the Minho River (Northwestern Iberian Peninsula). J. Appl. Ichthyol. 2011, 27, 56-59. [CrossRef]

23. Baglinière, J.L.; Elie, P. Les aloses (Alosa alosa et Alosa fallax spp.): Écobiologie et Variabilité des Populations; INRA-Cemagref: Paris, France, 2000; p. 275.

24. Aprahamian, M.; Alexandrino, P.; Antunes, C.; Cobo, F.; King, J.; Lambert, P.; Martin, J. Shads state of the art. In Report of the Workshop on Lampreys and Shads (WKLS), 27-29 November 2014, Lisbon, Portugal; ICES Document CM 2014/SSGEF: 13; International Council for the Exploration of the Sea: Copenhagen, Denmark, 2015; pp. 45-103. 206p.

25. Mateus, C.S.; Rodríguez-Muñoz, R.; Quintella, B.R.; Alves, M.J.; Almeida, P.R. Lampreys of the Iberian Peninsula: Distribution, Population Status and Conservation. Endanger. Species Res. 2012, 16, 183-198. [CrossRef]

26. Mota, M.; Rochard, E.; Antunes, C. Status of the Diadromous Fish of the Iberian Peninsula: Past, Present and Trends. Limnetica 2016, 29, 1-18.

27. Braga, H.O.; Pereira, M.J.; Morgado, F.; Soares, A.M.V.M.; Azeiteiro, U.M. Ethnozoological Knowledge of Traditional Fishing Villages about the Anadromous Sea Lamprey (Petromyzon marinus) in the Minho River, Portugal. J. Ethnobiol. Ethnomedicine 2019, 15, 71. [CrossRef] [PubMed]

28. Braga, H.O.; Pereira, M.J.; Musiello-Fernandes, J.; Morgado, F.; Soares, A.M.V.M.; Azeiteiro, U.M. The Role of Local Ecological Knowledge for the Conservation and Sustainable Fisheries of the Sea Lamprey (Petromyzon marinus Linnaeus, 1758) in the Iberian Peninsula. Ocean Coast. 2020, 198, 105345. [CrossRef]

29. Stratoudakis, Y.; Mateus, C.S.; Quintella, B.R.; Antunes, C.; de Almeida, P.R. Exploited anadromous fish in Portugal: Suggested direction for conservation and management. Mar. Policy 2016, 73, 92-99. [CrossRef]

30. Mota, M.; Sousa, R.; Bio, A.; Araujo, J.; Braga, C.; Antunes, C. Seasonal changes in fish assemblages in the River Minho tidal freshwater wetlands, NW of the Iberian Peninsula. Ann. De Limnol. Int. J. Limnol. 2014, 50, 185-198. [CrossRef]

31. Mota, M.; Bio, A.; Bao, M.; Pascual, S.; Rochard, E.; Antunes, C. New insights into biology and ecology of the Minho River Allis shad (Alosa alosa L.): Contribution to the conservation of one of the last European shad populations. Rev. Fish Biol. Fish. 2015, 25, 395-412. [CrossRef]

32. Sousa, R.; Dias, S.; Guilhermino, L.; Antunes, C. Minho River tidal freshwater wetlands: Threats to faunal biodiversity. Aquat. Biol. 2008, 3, 237-250. [CrossRef]

33. Mil-Homens, M.; Costa, A.M.; Fonseca, S.; Trancoso, M.A.; Lopes, C.; Serrano, R.; Sousa, R. Characterization of heavy-metal contamination in surface sediments of the Minho River Estuary by way of factor analysis. Arch. Environ. Contam. Toxicol. 2013, 64, 617-631. [CrossRef] [PubMed]

34. Oliveira, V.H.; Sousa, M.C.; Morgado, F.; Dias, J.M. Modeling the Impact of Extreme River Discharge on the Nutrient Dynamics and Dissolved Oxygen in Two Adjacent Estuaries (Portugal). J. Mar. Sci. Eng. 2019, 7, 412. [CrossRef]

35. Van Puijenbroek, P.J.T.M.; Buijse, A.D.; Kraak, M.H.S.; Verdonschot, P.F.M. Species and river specific effects of river fragmentation on European anadromous fish species. River Res. Appl. 2019, 35, 68-77. [CrossRef]

36. Almeida, P.; Quintella, B.; Dias, N. Movement of radio-tagged anadromous sea lamprey during the spawning migration in the River Mondego (Portugal). Hydrobiologia 2002, 483, 1-8. [CrossRef]

37. Paumier, A.; Drouineau, H.; Boutry, S.; Sillero, N.; Lambert, P. Assessing the relative importance of temperature, discharge, and day length on the reproduction of an anadromous fish (Alosa alosa). Freshw. Biol. 2020, 65, 253-263. [CrossRef]

38. Huang, Z. Drifting with Flow versus Self-Migrating-How Do Young Anadromous Fish Move to the Sea? iScience 2019, 19, 772-785. [CrossRef]

39. Marques, S.C.; Pardal, M.Â.; Primo, A.L.; Martinho, F.; Falcão, J.; Azeiteiro, U.; Molinero, J.C. Evidence for changes in estuarine zooplankton fostered by increased climate variance. Ecosystems 2018, 21, 56-67. [CrossRef]

40. Vicente-Serrano, S.; Trigo, R. Hydrological, Socioeconomic and Ecological Impacts of the North Atlantic Oscillation in the Mediterranean Region; Springer Science \& Business Media: Berlin, Germany, 2011.

41. Segurado, P.; Branco, P.; Avelar, A.P.; Ferreira, M.T. Historical changes in the functional connectivity of rivers based on spatial network analysis and the past occurrences of diadromous species in Portugal. Aquat. Sci. 2014, 77, 427-440. [CrossRef]

42. Trigo, R.M.; Pozo-Vázquez, D.; Osborn, T.J.; Castro-Díez, Y.; Gámiz-Fortis, S.; Esteban-Parra, M.J. North Atlantic Oscillation influence on precipitation, river flow and water resources in the Iberian Peninsula. Int. J. Climatol. J. R. Meteorol. Soc. 2004, 24, 925-944. [CrossRef]

43. DeCastro, M.; Lorenzo, N.; Taboada, J.; Sarmiento, M.; Alvarez, I.; Gómez-Gesteira, M. Influence of teleconnection patterns on precipitation variability and on river flow regimes in the Miño River basin (NW Iberian Peninsula). Clim. Res. 2006, 32, 63-73. [CrossRef]

44. Fatela, F.; Moreno, J.; Leorri, E.; Corbett, R. High marsh foraminiferal assemblages' response to intra-decadal and multi-decadal precipitation variability, between 1934 and 2010 (Minho, NW Portugal). J. Sea Res. 2014, 93, 118-132. [CrossRef] 
45. Mendes, R.; Saldías, G.S.; Decastro, M.; Gómez-Gesteira, M.; Vaz, N.; Dias, J.M. Seasonal and interannual variability of the Douro turbid river plume, northwestern Iberian Peninsula. Remote Sens. Environ. 2017, 194, 401-411. [CrossRef]

46. Costa, M.; Almeida, P.R.; Domingos, I.; Costa, J.; Correia, M.; Chaves, M.; Teixeira, C. Present status of the main shad's populations in Portugal. BFPP Bull. Fr. Peche Prot. Milieux Aquat. Bull. Fr. Peche Piscic. 2001, 362/363, 1109-1116. [CrossRef]

47. Donoso, M.C.; Vargas, N. Water Interactions with Energy, Environment, Food, and Agriculture; EOLSS Publishers Co. Ltd: Paris, France, 2009.

48. De la Rosa, J.; Araújo, M.; González-Pérez, J.; González-Vila, F.; Soares, A.; Martins, J.; Leorri, E.; Corbett, R.; Fatela, F. Organic matter sources for tidal marsh sediment over the past two millennia in the Minho River estuary (NW Iberian Peninsula). Org. Geochem. 2012, 53, 16-24. [CrossRef]

49. Larinier, M.; Travade, F. The design of fishways for shad. Bull. Fr. De La Peche Et De La Piscic. 2012, 364, 135-146. [CrossRef]

50. Neiva, A. Portuguese granites associated with Sn-W and Au mineralizations. Bull. Geol. Soc. Finl. 2002, 74, 79-101. [CrossRef]

51. Andrade, N.; Quintella, B.; Ferreira, J.; Pinela, S.; Povoa, I.; Pedro, S.; Almeida, P. Sea lamprey (Petromyzon marinus L.) spawning migration in the Vouga river basin (Portugal): Poaching impact, preferential resting sites and spawning grounds. Hydrobiologia 2007, 582, 121-132. [CrossRef]

52. Hansen, M.J.; Madenjian, C.P.; Slade, J.W.; Steeves, T.B.; Almeida, P.R.; Quintella, B.R. Population ecology of the sea lamprey (Petromyzon marinus) as an invasive species in the Laurentian Great Lakes and an imperiled species in Europe. Rev. Fish Biol. Fish. 2016, 26, 509-535. [CrossRef]

53. Beaulaton, L.; Taverny, C.; Castelnaud, G. Fishing, abundance and life history traits of the anadromous sea lamprey (Petromyzon marinus) in Europe. Fish. Res. 2008, 92, 90-101. [CrossRef]

54. Piet, G.J.; Quirijns, F.J.; Robinson, L.; Greenstreet, S.P.R. Potential pressure indicators for fishing, and their data requirements. ICES J. Mar. Sci. 2006, 64, 110-121. [CrossRef]

55. Stewart, K.R.; Lewison, R.L.; Dunn, D.C.; Bjorkland, R.H.; Kelez, S.; Halpin, P.N.; Crowder, L.B. Characterizing fishing effort and spatial extent of coastal fisheries. PLoS ONE 2010, 5, e14451. [CrossRef]

56. FAO. Report of the Expert Workshop to Estimate the Magnitude of Illegal, Unreported and Unregulated Fishing Globally; Food and Agricultureorganization of the United Nations: Rome, Italy, 2015. 